\title{
Effects of MCI-727, a New Antiulcer Agent, on Various Gastric and Duodenal Lesions in Experimental Animals
}

\author{
Satoshi Yamazaki, Makoto Kawamura, Mariko Kitsukawa, \\ Kentaro Ando, Issei Nitta, Akihiro Tobe and Susumu Okabe ${ }^{1}$ \\ Pharmaceuticals Laborator, Life Science Research Sector, Research Center, \\ Mitsubishi Kasei Corporation, Yokohama 227, Japan \\ 'Departmen of Applied Pharmacology, Kyoto Pharmaceutical University, \\ Misasagi, Yamashina, Kyoto 607, Japan
}

Received August 9, 1990 Accepred January 26, 1991

\begin{abstract}
Effects of a new antiulcer drug, MCI-727, on gastric and duodenal lesions, gastric secretion and gastric motility were studicd in comparison with cimetidine and teprenone. MCI-727 dose-dependently $(3-100 \mathrm{mg} / \mathrm{kg}$, p.o. or i.d.) inhibited the development of acute gastric or duodenal lesions such as pyrolus ligation-, waterimmersion stress-, indomethacin-, $\mathrm{HCl}-, \mathrm{HCl}$-ethanol-induced gastric lesions and cysteamine-induced duodenal lesions in rats and histamine-induced duodenal lesions in guinea pigs. These antiulcer effects exceeded those of cimetidine or teprenone. Repeated administration of MCI-727 (0.3-3 mg/kg/day, p.o., for 10 days) significantly promoted the spontaneous healing of acetic acid-induced chronic gastric ulcers. Concerning gastric acid secretion, MCI-727 selectively inhibited tetragastrin-stimulated acid secretion without effecting basal acid secretion and acid secretion by other stimuli. Cimetidine and teprenone inhibited acid secretion in several cases. MCI-727 and teprenone had inhibitory effects on gastric motility, although cimetidine had no effect. These results suggest that $\mathrm{MCl}-727$ has a wide spectrum of antiulcer activity, and its mode of antiulcer action is different from that of cimetidine or teprenone.
\end{abstract}

After the development of the histamine $\mathrm{H}_{2}-$ receptor blocker cimetidine, antiulcer therapeutics has progressed rapidly. However, refinements are still required, because some problems, such as recurrence of ulcer, remain to be solved. In our laboratory, we have attempted to develop new antiulcer agents by synthesizing a number of aryl ethanoneoxim derivatives and evaluating their efficacy on some experimental ulcer models. Among the active compounds, MCI-727 ((Z)-2-(4-methylpiperazin-1-yl)-1-4-(2-phenyl-ethyl) phenylethanone oxime hydrochloride monohydrate)
(Fig. 1) was sclected for further pharmacological evaluation as the most promising one with low toxicity. In the present study, we determined the effects of $\mathrm{MCI}-727$ on experimental gastric or duodenal ulcer models. We also examined its effects on gastric secretion

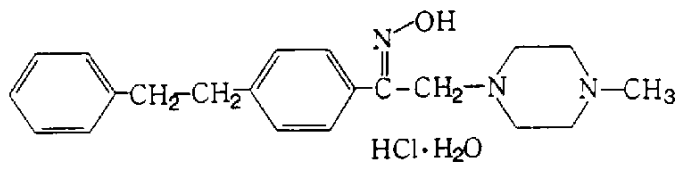

Fig. 1. Chemical structure of MCI-727. 
and motility to obtain information on the mechanism of its antiulcer action. In addition, the effects of MCI-727 were compared with those of teprenone, which has been reported to have antiulcer effects by enhancing the mucus and mucosal barrier (1), and the histamine $\mathrm{H}_{2}$-receptor blocker cimetidine.

\section{MATERIALS AND METHODS}

\section{Experimental animals}

Male Donryu rats $(200-250 \mathrm{~g}$, Japan SLC), female Wistar rats $(180-230 \mathrm{~g}$, Japan Laboratory Animals) and male Hartley guinea pigs $(300-350 \mathrm{~g}$, Japan Laboratory Animals) were used in the experiments.

\section{Experimental materials}

MCI-727 ((Z)-2-(4-methylpiperazin-1-yl)-14-(2-phenyl-ethyl) phenyl-ethanone oxime hydrochloride monohydrate) was synthesized in the Pharmaceuticals Laboratory, Research Conter, Mitsubishi Kasei Corporation. Other drugs used in the experiments were cimetidine (Sogoyakkou), teprenone (Eisai), indomethacin, tripelennamine, histamine dihydrochloride, cysteamine hydrochloride, 2-deoxy-D-glucose (Sigma), Gum. Arab., ethanol (Junsci Chemical), Twecn 80, hydrochlorić acid (Nacalai Tesque), acetic acid (Kishida Chemical), ether (Showa Ether), sodium pentobarbital (Pitman-Moorc), and tetragastrin (Sana).

In the experiments, MCI-727 and cimetidine were suspended in $2.5 \%$ gum arabic solution, and teprenone was suspended in a trace amount of Tween 80) solution. Each test drug, vehicle, or ulcerogenic agent was given in a volume of $0.2 \mathrm{ml} / 100 \mathrm{~g}$ body wt.

\section{Experimental ulcer}

Water-immersion stress-induced gastric erosions: Male Donryu rats, not fasted before experiments, were placed in a restraint cage (Natsume) and then immersed vertically to the level of the xiphoid process in a water bath $\left(23 \pm 1^{\circ} \mathrm{C}\right)(2,3)$. Sixteen hours later, the animals werc killed, and the stomach of each rat was removed and inflated by injecting 12 $\mathrm{ml}$ of $1 \%$ formalin to fix the inner and outer layers of the gastric wall. This formalin treatment was performed in all the following experiments. Subsequently, the stomach was incised along the greater curvature and cxamined for erosions in the glandular portion. Each drug or vehicle alone was given p.o. 30 min before stressing.

Shay's ulcers: Male Donryu rats were deprived of food but allowed free access to water for $48 \mathrm{hr}$ prior to experiments. Under ether anesthesia, the abdomen was incised and the pylorus ligated (4). Eighteen hours later, the animals were killed, and the stomach was examined for ulcers in the forestomach. Each drug or vehicle alone was given i.d. immediately after pylorus ligation.

Indomethacin-induced gastric erosions: Male Donryu rats were deprived of food but allowed frec access to water for $24 \mathrm{hr}$, and then indomethacin at $40 \mathrm{mg} / \mathrm{kg}$, suspended in $0.5 \%$ Tween 80 , was given p.o. (5). The animals were killed $6 \mathrm{hr}$ later, and the stomach was examined for erosions in the glandular portion. Each drug or vehicle alone was given p.o. $30 \mathrm{~min}$ before indomethacin treatment.

HCl-induced gastric erosions: Male Wistar rats were deprived of food and water for 24 $\mathrm{hr}$, and then $1 \mathrm{ml}$ of $0.6 \mathrm{~N} \mathrm{HCl}$ was given p.o. (6). The animals were killed $1 \mathrm{hr}$ later, and the stomach was examined for erosions in the glandular portion. Each drug or vehicle alone was given p.o. $30 \mathrm{~min}$ before $0.6 \mathrm{~N} \mathrm{HCl}$ treatmont.

HCl-ethanol-induced gastric erosions: Male Donryu rats were deprived of food and water for $24 \mathrm{hr}$, and then $1 \mathrm{ml}$ of HCl-ethanol $(35 \%$ $\mathrm{HCl}: 99.5 \%$ ethanol $=1: 50$ ) was given p.o. The animals were killed $1 \mathrm{hr}$ later, and the stomach was examined for erosions in the glandular portion. Each drug or vehicle alone was given p.o. $30 \mathrm{~min}$ before $\mathrm{HCl}$-ethanol treatment.

Cysteamine-induced duodenal ulcers: Female Wistar rats were deprived of food but allowed free access to water for $24 \mathrm{hr}$, and then cysteamine hydrochloride $(350 \mathrm{mg} / \mathrm{kg})$, dissolved 
in saline, was given s.c. (7). The animals were killed $22 \mathrm{hr}$ later, and the duodenum were examined for duodenal ulcers. Each drug or vehicle alone was given p.o. $30 \mathrm{~min}$ before cysteamine treatment.

Histamine-induced duodenal ulcers: Male Hartley guinea pigs were deprived of food but allowed free access to water for $24 \mathrm{hr}$, and then histamine dihydrochloride $(0.15 \mathrm{mg} / \mathrm{kg})$, dissolved in saline, was given i.m. eight times, at 30-min intervals (8). Thirty min after the final administration the animals were killed, and the duodenum was examined for duodenal lesions. Each drug or vehicle alone was given p.o. $10 \mathrm{~min}$ before histamine treatment.

Acetic acid-induced ulcers: Male Donryu rats, deprived of food but allowed free access to water for $24 \mathrm{hr}$, were used. Under pentobarbital $(35 \mathrm{mg} / \mathrm{kg}$, i.p.) anesthesia, the abdomen was incised and the anterior portion of the stomach was exposed. Then $0.05 \mathrm{ml}$ of $20 \%$ acetic acid $(\mathrm{v} / \mathrm{v})$ was injected into the submucosal layer in the antrum (9). After closure of the abdomen, the animals were maintained on rat chow and water ad libitum thereafter. Each drug or vehicle alone was given p.o. once daily (1:00 P.M.) starting from the third day after the operation for 10 days. The animals were killed $22 \mathrm{hr}$ after the final administration of drugs or vehicle, and the stomach was examined for ulcers.

Duration of antiulcer action: The duration of the antiulcer action of drugs was tested in the gastric lesion model induced by $\mathrm{HCl}$-ethanol. $\mathrm{HCl}$-ethanol was administered at various time intervals from $30 \mathrm{~min}$ to $16 \mathrm{hr}$, after oral treatment with drugs. The other procedures were the same as described in the method about HCl-ethanol-induced gastric erosions.

Lesion index: For the lesion index or ulcer index, the total length $(\mathrm{mm})$ of erosions induced by water-immersion stress, indomethacin, $\mathrm{HCl}, \mathrm{HCl}$-ethanol, histamine and the area $\left(\mathrm{mm}^{2}\right)$ of each ulcer induced by cysteamine and acetic acid were measured under a dissecting microscope $(\times 10)$. Each area $\left(\mathrm{mm}^{2}\right)$ of damaged forestomach in Shay's ulcers was measured under a dissecting microscope $(\times 10)$, summed, and arbitrarily classified into five degrees by an ulcer index as follows (10):

\begin{tabular}{|c|c|c|c|}
\hline Ulcerated arca $\left(\mathrm{mm}^{2}\right)$ & $1-6$ & $7-12$ & $13-18$ \\
\hline Ulcer index & 1 & 2 & 3 \\
\hline $\begin{array}{c}19-24 \\
4\end{array}$ & & or pe & ation \\
\hline
\end{tabular}

\section{Gastric secretory studies}

Male Donryu rats, which were deprived of food but allowed free access to water for 24 $\mathrm{hr}$, were used. Effects on gastric basal secretion were studied in pylorus ligated rats. Under ether anesthesia, the abdomen was incised and the pylorus ligated. Five hours after pylorus ligation, the animals were given an overdose of ether and the gastric contents were collected and analyzed for volume, acidity, and pepsin activity. Acidity was determined by automatic titration of gastric juice against $0.01 \mathrm{~N} \mathrm{NaOH}$ to $\mathrm{pH} 7$ (Autoburette and autotitrator, Radiometer, Copenhagen). Pepsin activity was determined by Anson's method using hemoglobin as a substrate (11). Titratable acid and pepsin output were expressed as $\mu \mathrm{Eq} / 5 \mathrm{hr}$ and $\mathrm{mg}$ tyrosin $/ 5 \mathrm{hr}$, respectively. Each drug or vehicle alone was given i.d. immediately after pylorus ligation.

Effects on stimulated gastric acid secretion were studied in acute gastric fistula rats (12). Under ether anesthesia, the abdomen was incised and a gastric fistula made by a polyethylene tube was attached in the fundic portion after ligation of the pyloric portion. After recovery from anesthesia, rats were fixed in a stainless steel cage, and gastric juice was collected every hour. The volume and acidity of the gastric juice were analyzed as described above. To stimulate gastric secretion, tetragastrin $(200 \mu \mathrm{g} / \mathrm{kg} / \mathrm{hr})$, histamine dihydrochloride $(8 \mathrm{mg} / \mathrm{kg} / \mathrm{hr})$, and 2-deoxy-Dglucose $(200 \mathrm{mg} / \mathrm{kg} / \mathrm{hr})$ were infused from the tail vein after recovery from anesthesia. Each drug or vehicle alone was given i.d. via a duodenal catheter $1 \mathrm{hr}$ before initiation of stimuli infusion. 


\section{Gastric motility studies}

Male Donryu rats were deprived of food but allowed free access to water for $24 \mathrm{hr}$ prior to the experiment. Gastric motility were measured in conscious normal rats using a miniature balloon method as described by Takeuchi and Nobuhara (13). Briefly, under ether anesthesia, the balloon ( $5 \mathrm{~mm}$ in diameter) and the support catheter were inserted into the stomach through a cautery hole in the greater curvature of the forestomach about $5 \mathrm{~mm}$ from the limiting ridge. They were tied in place so that they lay in the glandular part of the stomach. The balloon and catheter system was connected to a pressure transducer (LPU-0.1, Toyo Baldowin) and polygraph (NEC San-ei). The incision was then closed with a ligature, and the rats were placed on their right side in a stainless cage with a longitudinal slit at the bottom. Then the internal pressure of the balloon was recorded. The gastric motility index was expressed by maximal intra-gastric pressure in each $10 \mathrm{~min}$ period. Each drug was given i.d. $1 \mathrm{hr}$ after recovery from ether anesthesia by means of a catheter inserted into the duodenum. In the indomethacin pretreatment study, indomethacin $(40 \mathrm{mg} / \mathrm{kg}$, p.o. $)$ was given to the animals $5 \mathrm{hr}$ before ether anesthesia, and the other procedures were the same as in the normal rat study.

\section{Analysis of data}

Data are expressed as the mcan \pm S.E. Student's $t$-test was used to determine the statistical significance of data, and $\mathrm{P}<0.05$ (indicated by ${ }^{*}$ in the figures or tables) was regarded as significant.

\section{RESULTS}

Effects on various acute gastric ulcers or erosions

Watcr-immersion stress, indomethacin, $\mathbf{H C l}$, and $\mathrm{HCl}$-ethanol produced multiple, band-like or elongated erosions in the glandular stomach, and pylorus ligation produced multiple ulcers or perforation in the forestomach. The incidence of the lesions of control animals was $100 \%$ in cvery model. MCI-727 dose-dependently inhibited the development of the gastric mucosal lesions in these models (Table 1). On indomethacin- and $\mathrm{HCl}$-ethanol-induced erosions, the effects were significant at the lowest dose of $10 \mathrm{mg} / \mathrm{kg}$. With doses of 30 and 100 $\mathrm{mg} / \mathrm{kg}$, it also significantly inhibited the development of other gastric crosions. The inhibition rate at $30 \mathrm{mg} / \mathrm{kg}$ was $32.9 \%, 50.7 \%$, $66.4 \%, 64.5 \%$ and $94.1 \%$ for water-immersion stress-, Shay's, indomethacin-, $\mathrm{HCl}$ and $\mathrm{HCl}$ ethanol-induced lesions, respectively. Cimetidine $(100 \mathrm{mg} / \mathrm{kg})$ inhibited indomethacin- and

Table 1. Effects of MCI-727, cimetidine and teprenone on various acute gastric lesions in rats

\begin{tabular}{|c|c|c|c|c|c|c|}
\hline \multirow{2}{*}{ Drugs } & \multirow{2}{*}{$\begin{array}{c}\text { Dose } \\
(\mathrm{mg} / \mathrm{kg})\end{array}$} & \multicolumn{5}{|c|}{ Gastric lesions index } \\
\hline & & $\begin{array}{l}\text { stress } \\
(\mathrm{mm})\end{array}$ & Shay's & $\begin{array}{l}\text { indomethacin } \\
\qquad(\mathrm{mm})\end{array}$ & $\begin{array}{l}\mathrm{HCl} \\
(\mathrm{mm})\end{array}$ & $\begin{array}{l}\text { HCI-ethanol } \\
(\mathrm{mm})\end{array}$ \\
\hline Control & & $42.9 \pm 3.1$ & $4.7 \pm 0.3$ & $40.7 \pm 6.2$ & $97.8 \pm 6.1$ & $88.2 \pm 4.0$ \\
\hline \multirow[t]{3}{*}{$\mathrm{MCl}-727$} & 10 & $37.9 \pm 2.2$ & $3.9 \pm 0.6$ & $18.5 \pm 3.0^{*}$ & $73.8 \pm 8.5$ & $48.4 \pm 10.7^{*}$ \\
\hline & 30 & $28.8 \pm 4.3^{*}$ & $2.3 \pm 0.6^{*}$ & $13.7 \pm 4.3^{*}$ & $34.7 \pm 7.0^{*}$ & $5.2 \pm 1.9^{*}$ \\
\hline & 100 & $4.8 \pm 2.8^{*}$ & $1.2 \pm 0.2^{*}$ & $4.5 \pm 1.6^{*}$ & $24.9 \pm 6.5^{*}$ & $2.4 \pm 1.0^{*}$ \\
\hline Control & & $37.7 \pm 3.6$ & $4.8 \pm 0.2$ & $36.2 \pm 7.0$ & $97.8 \pm 6.1$ & $85.0 \pm 9.8$ \\
\hline Cimetidine & 100 & $26.9 \pm 4.7$ & $3.5 \pm 0.6$ & $15.8 \pm 7.2^{*}$ & $85.6 \pm 13.7$ & $40.6 \pm 7.9^{*}$ \\
\hline Control & & $40.0 \pm 3.6$ & $4.9 \pm 0.1$ & $47.6 \pm 7.2$ & $97.8 \pm 6.1$ & $78.0 \pm 7.5$ \\
\hline Teprenone & 100 & $45.2 \pm 2.8$ & $3.9 \pm 0.5$ & $23.4 \pm 6.0^{*}$ & $68.2 \pm 12.1^{*}$ & $55.0 \pm 11.8$ \\
\hline
\end{tabular}

$\mathrm{N}=7-11, *: \mathrm{P}<0.05$ 
$\mathrm{HCl}$-ethanol-induced erosions by $56.5 \%$ and $52.3 \%$, respectively, but it failed to inhibit the formation of water-immersion stress-, Shay's and $\mathrm{HCl}$-induced gastric lesions. Teprenone $(100 \mathrm{mg} / \mathrm{kg}$ ) also showed inhibitory activities on the crosions induced by indomethacin and $\mathrm{HCl}$. The inhibition rate was $50.8 \%$ and $30.2 \%$, respectively. It had no significant activities on water-immersion stress-, Shay's and HCl-ethanol-induced lesions.

\section{Effects on duodenal lesions}

Cysteamine produced one or two penetrating ulcers in the rat proximal duodenum, the incidence being more than $90 \%$. On the other hand, histamine produced multiple elongated lesions in the guinea pig duodenum, the incidence being $100 \%$. As shown in Table 2, MCI-727 inhibited the development of cysteamine- and histamine-induced duodenal ulcers at $100 \mathrm{mg} / \mathrm{kg}$; the inhibition rate was $55.5 \%$ and $52.6 \%$, respectively. Cimetidine $(100 \mathrm{mg} / \mathrm{kg})$ also inhibited both duodenal lesions; the inhibition rate was $84.3 \%$ and $76.2 \%$ for cysteamine- and histamine-induced duodenal lesions, respectively. Teprenone $(100$ $\mathrm{mg} / \mathrm{kg}$ ) failed to inhibit these duodenal lesions.
Table 2. Effects of MCI-727, cimetidine and teprenone on various acute duodenal lesions in rats and guinea pigs

\begin{tabular}{lccc}
\hline \multirow{2}{*}{ Drugs } & $\begin{array}{c}\text { Dose } \\
(\mathrm{mg} / \mathrm{kg}, \\
\text { p.o. })\end{array}$ & $\begin{array}{c}\text { cysteamine } \\
\left(\mathrm{mm}^{2}\right)\end{array}$ & $\begin{array}{c}\text { Distamine } \\
(\mathrm{mm})\end{array}$ \\
\cline { 3 - 4 } Control & & $54.1 \pm 8.9$ & $42.4 \pm 7.2$ \\
MCl-727 & 10 & $40.6 \pm 10.5$ & $53.7 \pm 7.9$ \\
& 30 & $33.6 \pm 8.6$ & $22.4 \pm 6.3$ \\
& 100 & $24.1 \pm 8.3^{*}$ & $20.1 \pm 7.0^{*}$ \\
Control & & $52.8 \pm 11.6$ & $32.4 \pm 4.7$ \\
Cimetidine & 100 & $8.3 \pm 3.8^{*}$ & $7.7 \pm 2.9^{*}$ \\
Control & & $42.8 \pm 12.1$ & $32.4 \pm 4.7$ \\
Teprenone & 100 & $37.3 \pm 12.9$ & $33.9 \pm 7.2$ \\
\hline N & & &
\end{tabular}

$\mathrm{N}=10-16,{ }^{*}: \mathrm{P}<0.05$

\section{Effects on acetic acid-induced ulcers}

The submucosal injection of $20 \%$ acetic acid produced visible round ulcers $\left(50-60 \mathrm{~mm}^{2}\right)$ in the stomach by the third day after injection. Thirteen days after injection, the mean ulcerated area in the control animals was $10-15$ $\mathrm{mm}^{2}$. As shown in Fig. 2, once daily administration of MCI-727 (0.3,1 and $3 \mathrm{mg} / \mathrm{kg})$ significantly accelerated the healing of the ulcers: the healing rate was $47.0 \%, 40.7 \%$, and

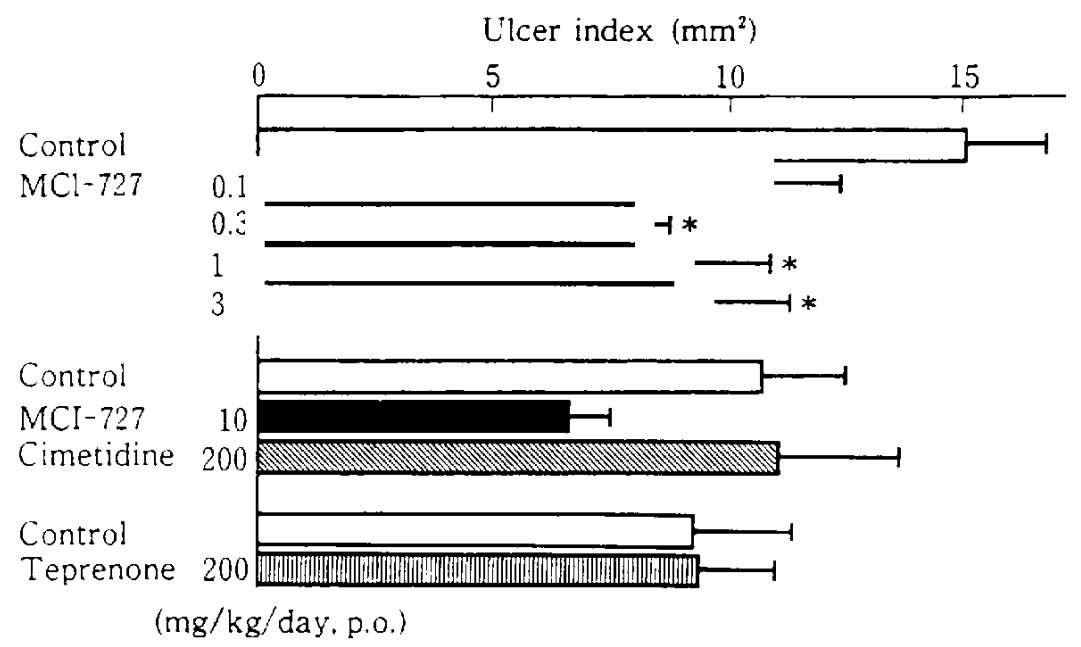

Fig. 2. Effects of MCI-727 and teprenone on healing of acetic acid-induced gastric ulcers in rats. Drugs were administrated once daily for 10 days. $\mathrm{N}=12-16,{ }^{*}: \mathrm{P}<0.05$. 
$37.2 \%$, respectively. On the other hand, once daily administration of cimetidine $(200 \mathrm{mg} / \mathrm{kg})$ and teprenone $(200 \mathrm{mg} / \mathrm{kg})$ failed to promote the healing of the ulcers.

\section{Duration of antiulcer action}

The durations of the antiulcer actions of the drugs on $\mathrm{HCl}$-ethanol induced lesions are shown in Fig. 3. MCI-727 $(30 \mathrm{mg} / \mathrm{kg})$, cimeti- dine $(200 \mathrm{mg} / \mathrm{kg}$ ) and tcprenone $(200 \mathrm{mg} / \mathrm{kg})$ produced almost the same inhibition of the lesion index in the 30 -min pretreatment schedule. The antiulcer action lasted at least $8 \mathrm{hr}$ in the case of MCI-727. On the other hand, the antiulcer effects of cimctidine and teprenone were observed only when they were administered $30 \mathrm{~min}$ before $\mathrm{HCl}$-ethanol treatment.

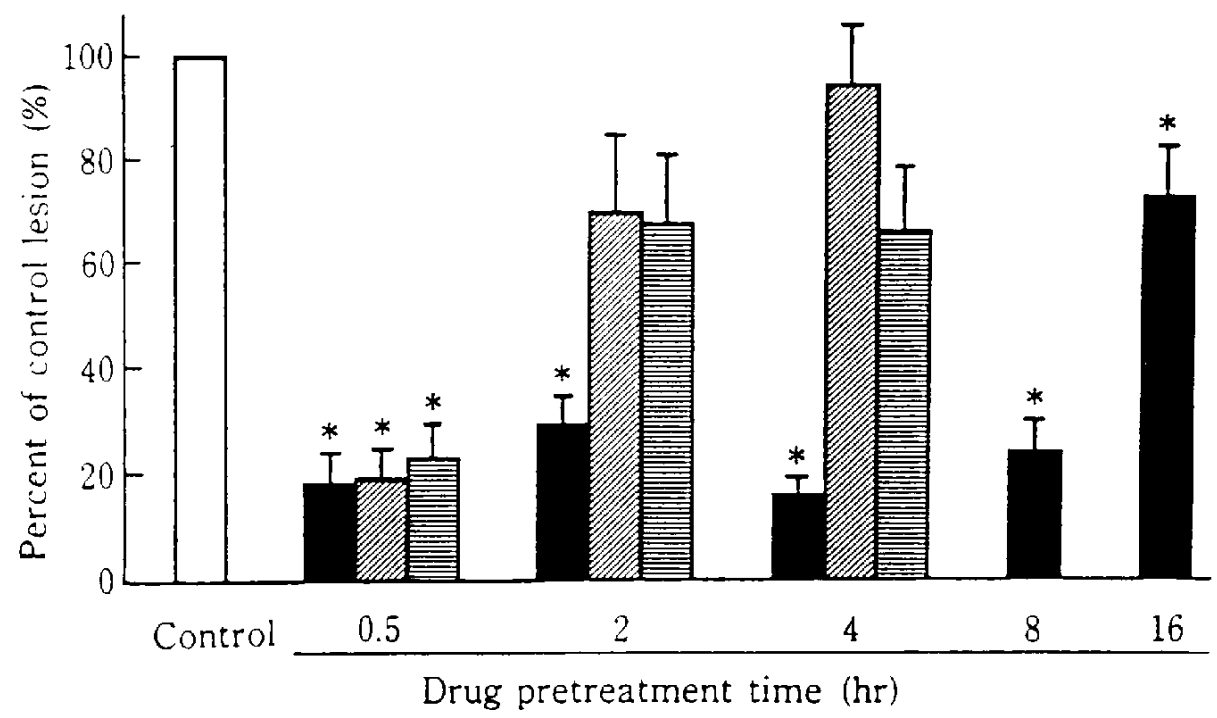

Fig. 3. The duration of antiulcer action of MCI-727. cimetidine and teprenone in HCl-ethanol-induced gastric lesions. MCI-727 (30 mg/kg, p.o.: $)$ ) cimetidine $(200 \mathrm{mg} / \mathrm{kg}$, p.o.: $)$ and teprenone $(200 \mathrm{mg} / \mathrm{kg}$, p.o.: 司) were treated before $\mathrm{HCl}$-ethanol at the time shown in the horizontal axis. $\mathrm{N}=8-10,{ }^{*}: \mathrm{P}<$ 0.05 .

Table 3. Effects of MCI-727, cimetidine and teprenone on gastric secretion in pylorus ligated rats

\begin{tabular}{|c|c|c|c|c|c|}
\hline \multirow{2}{*}{ Drugs } & \multirow{2}{*}{$\begin{array}{c}\text { Dose } \\
\text { (mg/kg, } \\
\text { i.d.) }\end{array}$} & \multirow{2}{*}{$\begin{array}{l}\text { No. of } \\
\text { rats }\end{array}$} & \multicolumn{2}{|c|}{ Gastric secretion } & \multirow[b]{2}{*}{$\begin{array}{l}\text { pepsin output } \\
\text { (mg Tyr } / 5 \mathrm{hr})\end{array}$} \\
\hline & & & $\begin{array}{l}\text { volume } \\
(\mathrm{ml} / 5 \mathrm{hr})\end{array}$ & $\begin{array}{l}\text { acid output } \\
(\mu \mathrm{Eq} / 5 \mathrm{hr})\end{array}$ & \\
\hline Control & & 6 & $3.6 \pm 0.84$ & $326 \pm 86.4$ & $57.8 \pm 12.1$ \\
\hline \multirow[t]{3}{*}{ MCI-727 } & 10 & 7 & $3.3 \pm 0.39$ & $286 \pm 49.9$ & $62.5+7.0$ \\
\hline & 30 & 6 & $3.4 \div 0.47$ & $302 \pm 71.7$ & $48.5 \pm 5.7$ \\
\hline & 100 & 5 & $2.0=0.31$ & $142 \pm 53.2$ & $29.3 \pm 6.1$ \\
\hline Control & & 6 & $3.8=0.13$ & $285 \pm 13.6$ & $84.1 \pm 6.2$ \\
\hline Cimetidine & 100 & 7 & $2.0 \pm 0.60^{*}$ & $72 \pm 35.5^{*}$ & $27.4+11.3^{*}$ \\
\hline Control & & 7 & $4.3 \pm 0.43$ & $319 \pm 43.4$ & $43.4 \pm 5.8$ \\
\hline Teprenone & 100 & 7 & $4.1+0.23$ & $332 \pm 33.4$ & $53.2 \pm 6.3$ \\
\hline
\end{tabular}

The pylorus was ligated for $5 \mathrm{hr} .{ }^{*}: \mathrm{P}<0.05$. 


\section{Effects on gastric secretion}

Pylorus ligation of control animals for $5 \mathrm{hr}$ resulted in an accumulation of gastric juice. The average values were $3-5 \mathrm{ml}, 250-400$ $\mu \mathrm{Eq}$ and $40-90 \mathrm{mg}$ tyrosine for volume, acid output and pepsin output, respectively. MCI$727(10-30 \mathrm{mg} / \mathrm{kg})$ and teprenone $(100$ $\mathrm{mg} / \mathrm{kg}$ ) did not have any effect on basal acid secretion (Table 3). At $100 \mathrm{mg} / \mathrm{kg}, \mathrm{MCl}-727$ tended to inhibit gastric secretion, but the effect was not statistically significant. Cimetidine $(100 \mathrm{mg} / \mathrm{kg})$ significantly inhibited acid and pepsin output by $74.7 \%$ and $67.4 \%$, respectively.

As for the cases of stimulated gastric acid secretion, MCI-727 (30 $\mathrm{mg} / \mathrm{kg})$ inhibited tetragastrin-stimulated gastric acid secretion for $1 \mathrm{hr}$, without affecting the histamineand 2-deoxy-D-glucose-stimulated gastric acid secretion (Fig. 4). Cimetidine $(100 \mathrm{mg} / \mathrm{kg})$ markedly inhibited acid secretion stimulated by tetragastrin, histamine and 2-deoxy-D-glu- cose. Teprenonc $(100 \mathrm{mg} / \mathrm{kg})$ also inhibited acid secretion by all stimuli for $1 \mathrm{hr}$.

\section{Effects on gastric motility}

The motility indexes of normal rats and indomethacin treated rats were $15-25$ and $50-70 \mathrm{cmH}_{2} \mathrm{O}$, respectively. MCl-727 $(3-30$ $\mathrm{mg} / \mathrm{kg}$ ) dose-dependently inhibited the indomethacin-induced gastric hypermotility (Fig. 5). Tepronone $(100 \mathrm{mg} / \mathrm{kg})$ also suppressed the hypermotility, but cimctidine (100) $\mathrm{mg} / \mathrm{kg}$ ) did not have any effect. In normal rats, MCI-727 suppressed the motility at doses over $10 \mathrm{mg} / \mathrm{kg}$ (Fig. 6). Teprenone (100) $\mathrm{mg} / \mathrm{kg}$ ) tended to depress the motility of normal rats, but the effect was not statistically significant. whercas cimetidine $(100 \mathrm{mg} / \mathrm{kg})$ did not have any effect.

\section{DISCUSSION}

In the present study, we examined the anti-

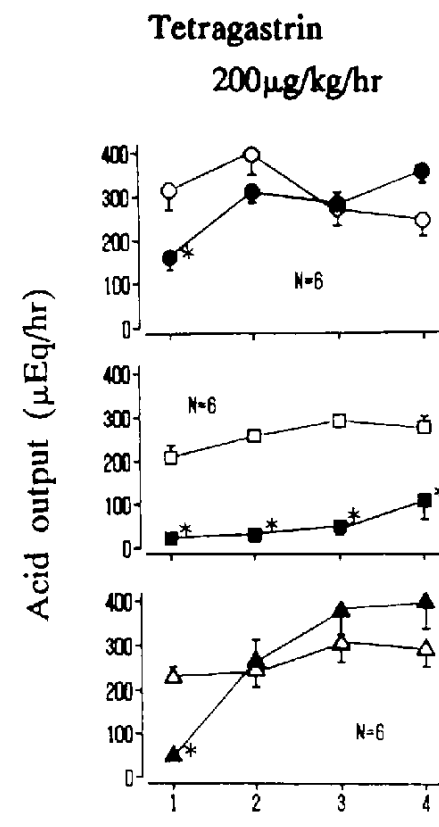

\section{Histamine $8 \mathrm{mg} / \mathrm{kg} / \mathrm{hr}$}
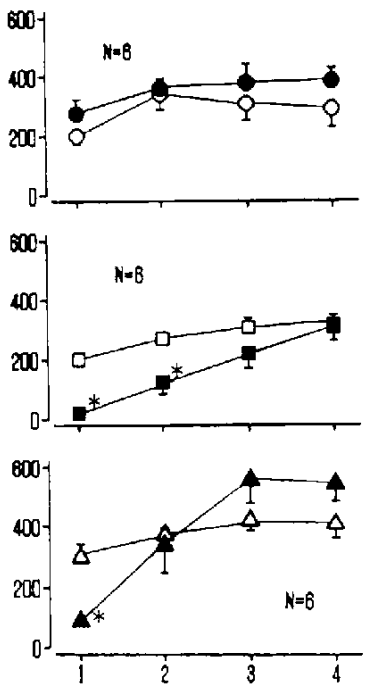

Time (hr)
2-deoxy-D-glucose $200 \mathrm{mg} / \mathrm{kg} / \mathrm{hr}$
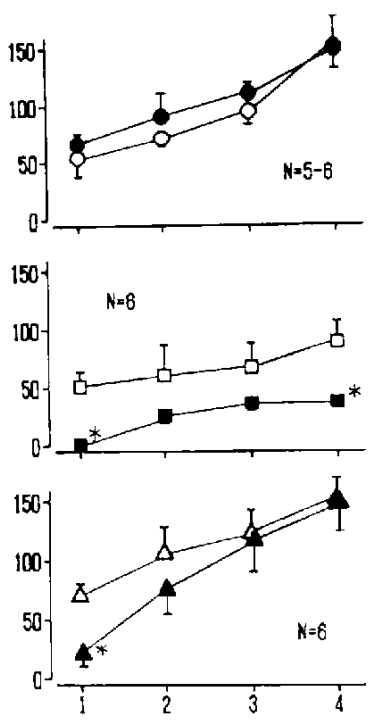

Fig. 4. Effects of $\mathrm{MCI}-727(30 \mathrm{mg} / \mathrm{kg}$, i.d.: $)$ ), cimetidine $(100 \mathrm{mg} / \mathrm{kg}$, i.d.: $\square$ ) and teprenone (100 $\mathrm{mg} / \mathrm{kg}$. i.d.: $\mathbf{A}$ ) on gastric secretion stimulated by tetragastrin, histamine and 2-deoxy-D-glucose in gastric fistula rats. Each open symbol shows the control value. * $\mathrm{P}<0.05$. 


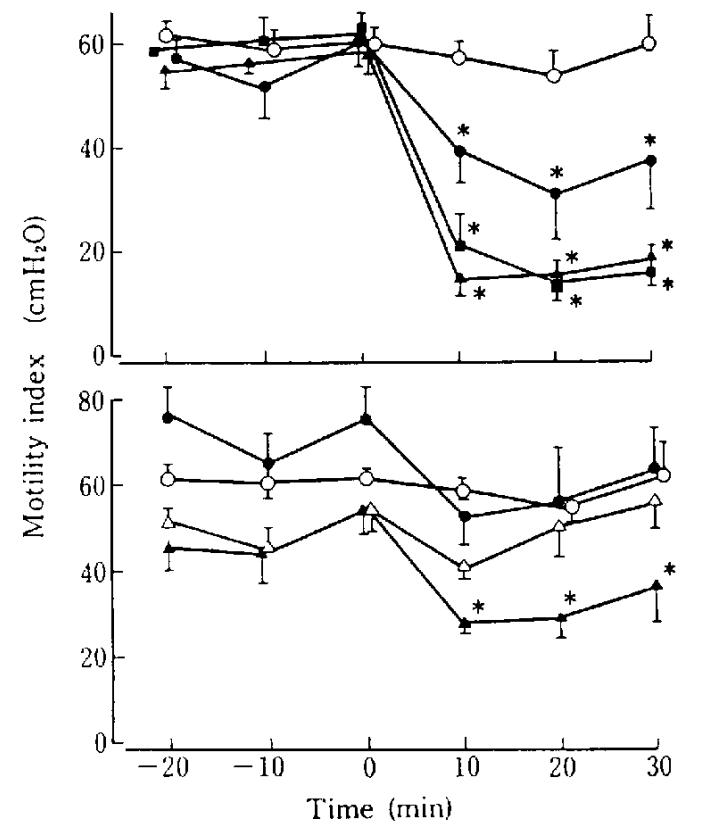

Fig. 5. Effects of MCI-727, cimetidine and teprenone on gastric hypermotility in indomethacin $(40 \mathrm{mg} / \mathrm{kg}$, p.o.) treated rats. $\mathrm{N}=6,{ }^{*}: \mathrm{P}<0.05$. Upper panel: Control (Gum. Arb.) ( ); MCI-727: $3 \mathrm{mg} / \mathrm{kg}$, i.d. (O) , $10 \mathrm{mg} / \mathrm{kg}$, i.d. ( $\Delta$ ), $30 \mathrm{mg} / \mathrm{kg}$, i.d. ( $\square$ ). Lower panel: Control (Gum. Arb.) ( $\bigcirc$ ); cimetidine, 100 $\mathrm{mg} / \mathrm{kg}$, i.d. ( $\bigcirc$ ); control (Tween) ( $\triangle$ ); teprenone, $100 \mathrm{mg} / \mathrm{kg}$, i.d. ( $\boldsymbol{\Delta}$ ).

ulcer effects of MCI-727 on various types of experimental ulcer models, to predict its possible clinical efficacy on peptic ulcers. As the first step to obtain insight into the pharmacological profiles of $\mathrm{MCI}-727$ as an antiulcer agent, effects of the compound on gastric secretion and gastric motility wcre also examined. In the experiments described above, the histamine $\mathrm{H}_{2}$-receptor blocker cimetidine, and teprenone, which is classified as an enhancer of defensive factors of the gastric mucosa (1), were used as the reference drug.

MCI-727 (3- $100 \mathrm{mg} / \mathrm{kg}$, p.o. or i.d.) dosedependently prevented the development of various acute gastric and duodenal lesions (water-immersion stress-, Shay's, indomethacin-, $\mathrm{HCl}$, $\mathrm{HCl}$-ethanol-induced gastric ulcers or erosions and cysteamine-, histamine-induced duodenal ulcers or lesions). Its antiulcer

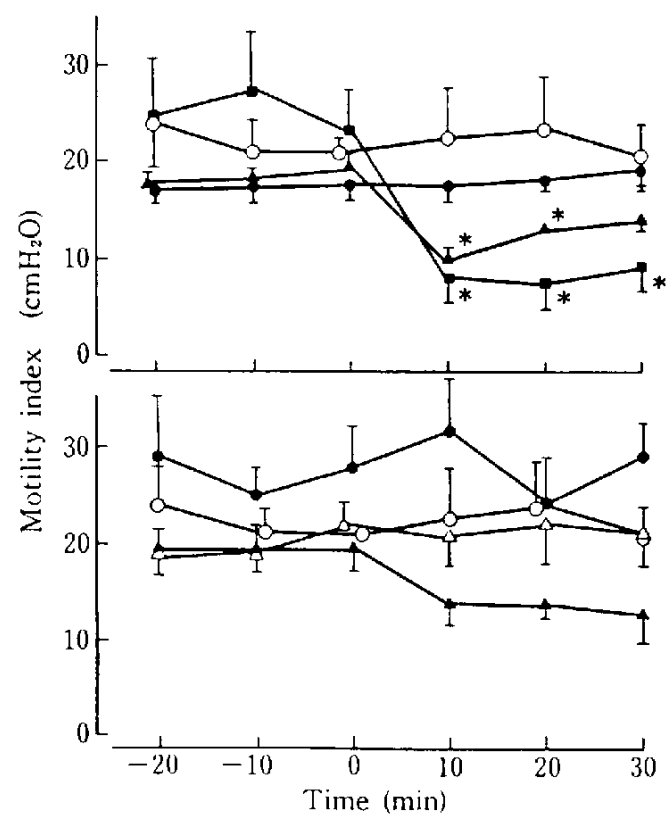

Fig. 6. Effects of MCI-727, cimetidine and teprenone on gastric motility in normal rats. $\mathrm{N}=5-6,{ }^{*}: \mathrm{P}<$ 0.05. Upper panel: Control (Gum. Arb.) ( $($ ) ;CI$727: 3 \mathrm{mg} / \mathrm{kg}$, i.d. (O), $10 \mathrm{mg} / \mathrm{kg}$, i.d. (A), 30 $\mathrm{mg} / \mathrm{kg}$, i.d. (G). Lower panel: Control (Gum. Arb.) (O); cimetidine, $10 \mathrm{~K}) \mathrm{mg} / \mathrm{kg}$, i.d. (O); control (Tween) $(\triangle)$; teprenone, $100 \mathrm{mg} / \mathrm{kg}$, i.d. (A).

effects were marked in gastric lesions rather than in duodenal lesions. MCI-727 (0.3-3 $\mathrm{mg} / \mathrm{kg}$, p.o.) also promoted the healing of acetic acid-induced gastric ulcers. However its effects were not dose-dependent; and at 10 $\mathrm{mg} / \mathrm{kg}$, the effect was not statistically significant. So, there might be an optimal dose of MCI-727 that manifests the beneficial effect on the healing of these chronic ulcers, like what has been reported for arbaprostil (14). The difference in effective dose between acute and chronic ulcer models may suggest the possibility that the antiulcer activity of MCI-727 was increased by consecutive administration. Cimetidine $(100 \mathrm{mg} / \mathrm{kg})$, which inhibits gastric basal acid secretion by $74.7 \%$, also showed antiulcer effects on several gastric or duodenal lesions. This drug, however, showed no effects on Shay's ulcers and $\mathrm{HCl}$-induced erosions, 
and it failed to promote the healing of acetic acid-induced gastric ulcers. Furthermore, teprenone $(100 \mathrm{mg} / \mathrm{kg})$ exhibited antiulcer effects on only two kinds of gastric lesions (indomethacin- and $\mathrm{HCl}$-induced gastric lesions). The duration of the antiulcer action of MCI-727 was also compared with those of cimetidine and teprenone in the HCl-ethanolinduced gastric ulcer model, and it was found to be more than four times longer than those of cimetidine and teprenone. So these differences in the duration of action may influence the antiulcer action of these three drugs, especially in Shay's, water-immersion stress-, acetic acid-induced ulcer models.

From these results on experimental ulcers, it is suggested that the antiulcer effects of MCI727 are superior to those of cimetidine or teprenone in both potency and antiulcer spectrum.

Concerning the gastric acid secretion, cimetidine $(100 \mathrm{mg} / \mathrm{kg})$ inhibited not only the basal acid secretion in pylorus ligated rats, but the acid secretion stimulated by tetragastrin, histamine and 2-deoxy-D-glucose in acute gastric fistula rats. Although not as clearly as cimetidine, teprenone $(100 \mathrm{mg} / \mathrm{kg})$ also showed the similar inhibitory propensities on stimulated acid secretion. On the other hand, MCI- 727 only inhibited tetragastrin-stimulated acid secretion without any significant effect on other experimental conditions. Little has been reported on drugs that can selectively inhibit acid secretion due to gastrin receptor stimulation except for the case of secretin $(15,16)$. Secretin, one of the gastrointestinal hormones, is reported to have antiulcer effects $(17,18)$; and it has been used for peptic ulcer disease. Considering these conditions, participation of endogenous secretin may be postulated as one of the probable mechanisms of the gastrinselective antisecretory action of MCI-727.

In addition to the acid secretion, the role of gastric motility in the pathogenesis of gastric lesions has been reported. For example, Mersereau and Hinchey (19) and Takeuchi et al. (20) suggested that gastric hypermotility might be a major factor in the genesis of gas- tric lesions induced by indomethacin, by showing the close correlation between the lesion index and the motility index. Similar hypotheses have also been reported in other experimental ulcer models, including water-immersion stress- and various necrotizing agent-induced gastric lesions $(13,21,22)$. Moreover, some antiulcer drugs such as beguhexate. $C D$ and secretin were reported to possess inhibitory effects on gastric motility in normal rats or humans $(23-25)$. So, we examined the effects of MCI-727 on the gastric motility under two different conditions: One is gastric motility in normal rats (A), and the other is gastric hypermotility in indomethacin $(40 \mathrm{mg} / \mathrm{kg}$, p.o.) pretreated rats (B). MCI-727 depressed the gastric motility in both $\mathrm{A}$ and $\mathrm{B}$. The minimal effective dose in $A$ is $10 \mathrm{mg} / \mathrm{kg}$, i.d. and in $B, 3 \mathrm{mg} / \mathrm{kg}$, i.d. Teprenone $(100$ $\mathrm{mg} / \mathrm{kg}$, i.d.) also depressed gastric motility in $\mathrm{B}$ and showed a tendency of depression in $\mathrm{A}$. As for cimetidine ( $100 \mathrm{mg} / \mathrm{kg}$, i.d.), there was no significant effects on the gastric motility. As far as gastric motility is concerned, the effects of MCI-727 resemble those of teprenone, although the potency was much higher in MCI-727. Considering these results and the findings described above, the antiulcer effects of MCI-727 and teprenone may partly depend on the depression of gastric motility.

In summarizing the present results, the pharmacological profiles of MCI-727 may be different from those of cimetidine and teprenone in the sense that only MCI-727 selectively inhibits tetragastrin-stimulated acid secretion and depresses the gastric motility. On the other hand, we have already obtained the preliminary result that the plasma secretin level increased by oral administration of MCI-727 in rats (26). Taking these results into account, it may well be suggested that secretin will become an important clue for clarifying the precise mechanism for the potent and wide spectrum of the antiulcer effects of MCI-727.

Although the detailed investigations are further required, the present results suggest that MCI-727 may be clinically useful for the treatment of peptic ulcers. 


\section{REFERENCES}

1 Murakami, M., Oketani, K., Fuiisaki, H., Wakabayashi, T. and Ohgo, T.: Antiulcer effect of geranylgeranylacetone, a new acyclic polyisoprenoid on experimentally induced gastric and duodenal ulcers in rats. Arzneimittelforschung 31. $799-804$ (1981)

2 Takagi, K. and Okabe, S.: The effects of drugs on the production and recovery process of the stress ulcer. Japan. J. Pharmacol. 18, 9-18 (1968)

3 Takagi, K., Kasuya, Y. and Watanabe, K.: Studies of the drugs for peptic ulcer, a reliable method for producing stress ulcer in rats. Chem. Pharm. Bull. (Tokyo) 12, 465-472 (1964)

4 Shay, H., Komarov, S.A., Fels, S.S., Meranze, D., Gruentein, M. and Sipet, H.: A simple method for uniform production of gastric ulceration in the rat. Gastroenterology 5, 43-61 (1945)

5 Okabe, S., Ohtsu, K., Takeuchi, K. and Takagi, $\mathrm{K}$ : Effect of L-glutamine on indomethacin-induced gastric lesions in the rat. Japan. J. Pharmacol. 24, 169-171 (1974)

6 Robert, A., Nezamis, L.E., Lancaster, C. and Hanchar, A.J.: Cytoprotection by prostaglandins in rats. Gastroenterology 77, 433-443 (1979)

7 Robert, A., Nezamis, J.E., Lancaster, C. and Badalamenti, J.N.: Cysteamine-induced duodenal ulcers: A new model to test antiulcer agents. Digestion 11, 199 - 214 (1974)

8 Eagleton, G.B. and Watt, J.: Acute duodenal ulceration in guinea pig induced by repeated intramuscular injection of aqueous histamine. $J$. Pathol. Bacteriol. 93, 694-696 (1967)

9 Takagi, K., Okabe, S. and Saziki, R.: A new method for thc production of chronic gastric ulcer in rats and effect of several drugs on its healing. Japan. J. Pharmacol. 19, 418-426 (1969)

10 Yamanoto, O., Okada, Y. and Okabe, S.: Effects of a proton pump inhibitor, omeprazole, on gastric secretion and gastric and duodenal ulcers or erosions in rats. Dig. Dis. Sci. 29, $394-401$ (1984)

11 Anson, M.L.: The estimation of pepsin, trypsin, papain and cathepsin with hemoglobin. J. Gen. Physiol. 22, 79-89 (1938)

12 Konturec, S.J.: Effect of graded doses of pentagastrin, histamine and 2-dcoxy-D-glucose on gastric secretion and motility in conscious rat. Scand. J. Gastroenterol. 3, 572-576 (1968)

13 Takeuchi, K. and Nobuhara, Y.: Inhibition of gastric motor activity by 16,16 -dimethyl prostaglandin $E_{2}$. Dig. Dis. Sci. 30, $1181-1188$ (1985)

14 Okabe, S., Jino, H. and Nishida, A.: Effect of 15(R)-15-methyl prostaglandin $E_{2}$ (arbaprostil) on gastric secretion and various gastric lesions in- duced in rats. Japan. J. Pharmacol. 40, 329-337 (1986)

15 Johnson, L. and Grossman, M.: Secretin: the enterogastrone released by acid in the duodenum. Am. J. Physiol. 215, $885-888$ (1968)

16 Lawwrence, W.Y.: Effect of secretin on gastric acid secretion in response to cholinergic stimuli. Gastroenterology 59, 510-517 (1970)

17 Stanislaw, J. and Konturek, M. D.: The effect of secretin on gastric acid secretion and peptic ulcers induced by pentagastrin in cats with intact or resected duodenum. Am. J. Dig. Dis. 13, $874-881$ (1968)

18 Chyo, H., Ohshiro, I., Sakai, Y. and Saito, T.: Effects of secretin (Eisai E-286) on experimental ulcers in rats. J. New Remedies Clinics 23, 1287 1305 (1974)

19 Mersereau, W.A. and Hinchey, E.J.: Prevention of indomethacin-induced gastric hypercontractility: a mucosal protective mechanism of prostaglandin $\mathrm{E}_{2}$. Gastroenterology 78, 1221 (Abstract) (1980)

20 Takeuchi, K., Ueki, S. and Okabe, S.: Importance of gastric motility in the pathogenesis of indomethacin-induced gastric lesions in rats. Dig. Dis. Sci. 31, 1114-1122 (1986)

21 Thomas, G., Felix, W.L., Sally, B., Hirabayashi, K. and Paul, H.G.: Gastric motility is stimulated but overall blood flow is unaffected during cold restraint in the rat. Gastroenterology 91, 141-148 (1986)

22 Ohno, T., Hirose, N., Uramoto, H., Ishihara, T. and Okabe, S: Surface epithelial cell damage induced by restraint and water-immersion stress in rats. Effects of 16,16-dimcthyl prostaglandin $E_{2}$ on stress-induced gastric lesions. Japan. J. Pharmacol. 45, 405-415 (1987)

23 Nagai, T., Ohtani, K., Tsukinogi, Y., Hirose, F., Shimono, N. and Tsutsumiuti, M.: Effects of beguhexate-CD on experimental ulcers, gastric secretion and gastric motility. Prog. Med. 6, Supp. 1, 2068 - 2076 (1986)

24 Dinoso, V.P., Chey, W.Y., Hendrics, J. and Kuber, S.H.: Intestinal mucosal hormones and motor function of stomach in man. J. Appl. Physiol. 26, 325-329 (1969)

25 Johnson, L.P., Brown, J.C. and Magee, D.F.: Eifects of secretin and cholecystokinin-pancreozymin extracts on gastric motility in man. Gut 7, 5257 (1966)

26 Kawamura, M., Yamazaki, S., Kitsukawa, M., Ando, K. and Tobe, A.: Increasing effect of MCI727 , a new anti-ulcer agent, on plasma secretin level in rats and dogs. Japan. J. Pharmacol. 52, Supp. 1, 244P (1990) 